\title{
A Contrast Study between Outstanding Academic and Non-Academic Writers from middle Ages to the End of 19th Century in the United Kingdom
}

\author{
Xiangbin Tian and Wantian Huang \\ Tianhe College of Guangdong Polytechnic Normal University \\ 638 Xingtaisan Road, Taihe, Guangzhou, P. R. China \\ *1253183232@qq.com, fionauong@163.com \\ Corresponding author: Xiang-bin Tian
}

Keywords: Contrast; Academic; Non-academic; Higher Education; Literature

\begin{abstract}
English literature has been leading the world literature and a lot of world-famous literary giants in UK, such as Shakespeare, Dickens, Joyce and so on, have made great contribution to human civilization. It is worth exploring whether this flourishing phenomena is related to the higher education. The paper will interpret the relationship between the outstanding writers and the high education from the medieval to the 19th century in UK. The outstanding writers will be divided into two groups, One group consists of the academic writers who once studied in university and got at least BA, such as Milton, Wordsworth, and Scott. Another group is non-academic writers who did not go to university or who once studied in a university but without any degrees, such as Shakespeare, Dickens, Shelley, etc.. The contrast of two groups will be done according to their achievements and their influence on the world literature. The analysis has found out that higher education in UK did influence the development of English literature, but it is not the key factor because the achievements and influence in the group of non-academic writers tower above that of academic writers during these ages.
\end{abstract}

\section{Introduction}

Literature reflects the development of the education in any country and higher education should influence the literary achievements. In order to make sure whether college education influenced the writers and their achievements greatly in UK, the contrast study on the famous English writers and their educational background is necessary. This research divides the British outstanding writers into two groups: the academic writers and the non-academic writers. The academic writers are those who had completed his study in a college or a university. And the non-academic writers are those who had not completed their higher education degrees, even though he once went to college.

Up to now, nobody completely focuses on the studies between academic writers and non-academic writers in China, let alone the division of the Medieval to the end of 19th century. In other words, none of an authoritative study has mentioned that academic literary writers are superior to non-academic ones.

This study will challenge to contrast English literature in a new way, in which the text will define an original classification, choosing world-famous writers in UK and classify them into two groups from the medieval age to the end of 19th century in order to explore whether the higher education influence the literary creation.

\section{Definitions of the Research}

Since the paper involve in some terms that means differently with its own meaning, the paper will have it redefined. Such as "academic" and "non-academic". Furthermore, it's necessary to define the outstanding writers and literature era. 
The Definition of Academic Writers and Non-academic Writers. In this research, the writers refer to the literary creators, such as novelists, poets, dramatists, and essayists, not including literary critics. The paper studies mainly the "academic writers" and "non-academic writers".

In this paper, "academic writer" refers to the writer who was educated in college or university and completed his or her study with a degree, such as Geoffrey Chaucer, Francis Bacon and University Wits. The writer who once went to a university but did not finish one's study with at least BA does not belong to this group $[1,2,3]$.

"Non-academic writer" means the writer who did not go to university or did not complete one's study in the university without any degree, such as Shakespeare who only attended a local grammar school and Shelley who once studied in Oxford University, but was expelled from the University for publishing The Necessity of Atheism. Charles Dickens, Jane Austen and Bronte Sisters are in this group $[4,5,6]$.

Outstanding Writers and the Selection of Literature Era. Outstanding writers here refer to those who have been continuously mentioned in the history of literature, whose works have become classic and popular, and who are read or studied from generation to generation. What's more, they and their works have great reputation in the world literature and influenced a lot of famous writers at home and abroad.

The research will select the outstanding writers from Medieval Age to the end of 19th century in the United Kingdom. The exact selection will begin from Chaucer's time, because several famous works were anonymous before the era, such as Beowulf and Arthurian romances. On the other hand, Geoffrey Chaucer is known as the Father of English literature and widely considered the greatest English poet of the Middle Age. He is the first person to use London dialect to write his poetry, founding of modern English. The end of 19th century refers to the selected writers who finished their main works before 1900, such as Thomas Hardy. According to above definitions, outstanding writers are selected and divided into five levels as follows [1,2,6,8]:

Table 1 The list of outstanding writers from medieval age to the end of $19^{\text {th }}$ century

\begin{tabular}{|c|c|c|}
\hline Scores & Rank & Writers \\
\hline 20 & First & William Shakespeare (1564-1616) \\
\hline 18 & Second & Charles Dickens(1812-1870), G.B. Shaw (1856-1950) \\
\hline 16 & Third & $\begin{array}{l}\text { Geoffrey Chaucer (1343-1400), John Milton (1608-1674), William Wordsworth (1770-1850), } \\
\text { Jane Austen (1775-1817), George Gordon Byron (1788-1824), John Keats (1795-1821), } \\
\text { Percy Bysshe Shelley (1792-1822), William M. Thackeray (1811-1863), Charlotte Bronte } \\
\text { (1816-1855), Emily Bronte (1818-1848), Thomas Hardy (1840-1928), Rudyard Kipling } \\
\text { (1865-1936) (12 writers) }\end{array}$ \\
\hline 14 & Fourth & $\begin{array}{l}\text { Edmund Spencer(1522-1599), Francis Bacon(1561-1626), Ben Jonson(1572-1637), John } \\
\text { Donne(1572-1631), John Bunyan(1628-1688), Daniel Defoe (1660-1731), Jonathan } \\
\text { Swift(1667-1745), Alexander Pope (1688-1744), Samuel Richardson (1689-1761), Henry } \\
\text { Fielding (1707-1754), Samuel Johnson (1709-1784), Laurence Sterne(1713-1768), Thomas } \\
\text { Gray(1716-1771), William Blake (1757-1827), Robert Burns (1759-1796), Walter } \\
\text { Scott(1771-1832), Alfred Tennyson(1809-1892), Elizabeth Gaskell (1810-1865), Robert } \\
\text { Browning(1812-1889), George Eliot (1819-1880), Oscar Wilde (1854-1900) (21 writers) }\end{array}$ \\
\hline 12 & Fifth & $\begin{array}{l}\text { Thomas More (1478-1535), John Dryden (1631-1700), Christopher Marlowe (1564-1593), } \\
\text { Joseph Addison (1672-1719), Tobias George Smollett (1721-1771), Oliver Goldsmith } \\
\text { (1730-1774), Richard B. Sheridan (1751-1816), Samuel Taylor Coleridge (1772-1834), } \\
\text { Robert Southey (1774-1843), Charles Lamb(1775-1834), Mary Shelly(1797-1851), Thomas } \\
\text { Hood (1799-1845), Elizabeth Barret Browning (1806-1861), Anthony Trollope (1815-1882), } \\
\text { Anne Bronte (1820-1849), Matthew Arnold (1822-1888), William Wilkie Collins } \\
\text { (1824-1889), George Meredith (1828-1909), Lewis Carroll (1832-1898),William Morris } \\
\text { (1834-1896), Samuel Butler (1835-1902), Robert Louis Stevenson (1850-1894), Joseph } \\
\text { Conrad (1857-1924), H. G. Wells (1866-1946) } \\
\text { (24 writers) }\end{array}$ \\
\hline
\end{tabular}


All of them will be divided into five levels as the chart showed, starting from Shakespeare who will be marked 20 points as the first level; what's more, Charles Dickens and G.B. Shaw will be marked 18 points as the second level, and analogy.

Some famous writers have not been put into this list because their works have not been passed on to the generation nor have significant influence, such as the writers of University Wits. This study only chooses the gifted Christopher Marlowe as the representative.

\section{Classification of Academic Writers and Non-academic Writers}

All the outstanding writers selected above have been divided into two groups: the academic group and non-academic group. They will be given different scores according to their great achievements, reputation and influence.

The Group of the Academic Writers. From the list of the outstanding writers, those leading and typical writers, who once studied in university and got at least BA, are grouped into academic writers. The following table is the list and the scores of this group $[1,2,6,7,8]$.

Table 2 The outstanding academic writers

\begin{tabular}{|c|c|c|}
\hline Rank & Outstanding Writers & Scores \\
\hline \multirow{5}{*}{$\begin{array}{l}\text { Third } \\
\text { Level }\end{array}$} & Geoffrey Chaucer (1343-1400) & \multirow{5}{*}{$16 \times 5$} \\
\hline & John Milton (1608-1674) & \\
\hline & William Wordsworth (1770-1850) & \\
\hline & George Gordon Byron (1788-1824) & \\
\hline & Thomas Hardy (1840-1928) & \\
\hline \multirow{11}{*}{$\begin{array}{c}\text { Fourth } \\
\text { Level }\end{array}$} & Edmund Spencer(1522-1599) & \multirow{11}{*}{$14 \times 11$} \\
\hline & Francis Bacon(1561-1626) & \\
\hline & John Donne(1572-1631) & \\
\hline & Jonathan Swift(1667-1745) & \\
\hline & Henry Fielding (1707-1754) & \\
\hline & Laurence Sterne(1713-1768) & \\
\hline & Thomas Gray(1716-1771) & \\
\hline & Walter Scott(1771-1832) & \\
\hline & Alfred Tennyson(1809-1892) & \\
\hline & Robert Browning(1812-1889) & \\
\hline & Oscar Wilde (1854-1900) & \\
\hline \multirow{12}{*}{$\begin{array}{l}\text { Fifth } \\
\text { Level }\end{array}$} & Thomas More (1478-1535) & \multirow{12}{*}{$12 \times 12$} \\
\hline & John Dryden (1631-1700) & \\
\hline & Christopher Marlowe (1564-1593) & \\
\hline & Joseph Addison (1672-1719) & \\
\hline & Oliver Goldsmith (1730-1774) & \\
\hline & Samuel Taylor Coleridge (1772-1834) & \\
\hline & Robert Southey (1774-1843) & \\
\hline & Matthew Arnold (1822-1888) & \\
\hline & Lewis Carroll (1832-1898) & \\
\hline & William Morris (1834-1896) & \\
\hline & Robert Louis Stevenson (1850-1894) & \\
\hline & H. G. Wells (1866-1946) & \\
\hline Total & Total Scores & 378 \\
\hline
\end{tabular}

The scores given are according to their achievements, influence and popularity. There are no writers in first and second level writers in this group because the first and second level writers include only Shakespeare, Dickens and G. B. Shaw who belong to non-academic group. The total 
points in this group are 366.

The Group of the Non-academic Writers. Some outstanding writers mentioned above can be put into non-academic group because these writers got only a little schooling education. That means they did not go to university to study or some of them went to a university for a period but did not complete their education there. For example, John Keats once was registered as a medical student at Guy's Hospital which is part of King's College London now, but he gave up medicine for poetry. William M. Thackeray studied at Cambridge but he left it without taking a degree. The following table is the list of the outstanding non-academic writers $[2,6,8]$.

Table 3 The outstanding non-academic writers

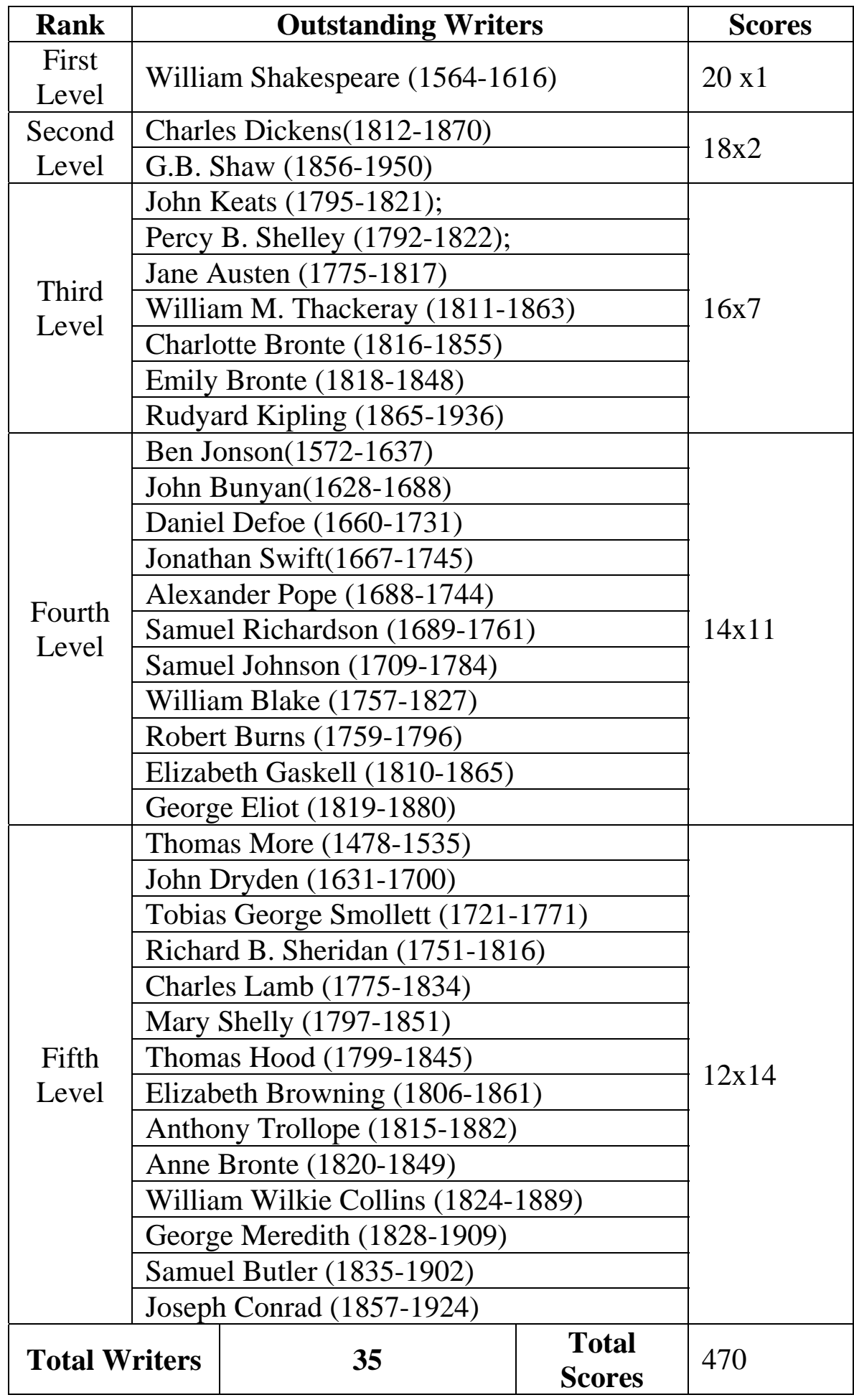




\section{Comparative Analysis of Academic and Non-academic Writers}

The contrast shows us that the non-academic writers are evidently superior to the academic ones. In this research, 63 outstanding writers from the Medieval Age to the end of $19^{\text {th }}$ century in the United Kingdom have been selected, of which academic writers are only 28, while non-academic writers account for 45 .

Analyzing from the scores, the non-academic writers account for 470 points, but the academic writers are only 378 points. The non-academic group towers a lot over the academic group. Moreover, All of the first level and the second level writers are in the non-academic group. It shows that the higher education is not closely related to literary creation.

\section{Conclusion}

The analysis of the data above shows us that the achievements and influence of outstanding non-academic writers far surpass that of academic writers. The contrast of the data above tells us that the higher education is not the key factor for literary creation although university is called ivory tower. William Shakespeare has been known as the greatest writer and the world's pre-eminent dramatist. Ben Jonson believed that "He is the greatest playwright all over the world, not of an age, but for all the time"[6]. However, he only attended a grammar school. Charles Dickens is regarded as the outstanding representative novelist of critical realism. His poor family forced him to leave school to work in a factory. Both of them have made great contribution to the world literature and have given us the realistic society of their age. It can be concluded that social and life experience is an important factor for literary creation.

However, it is not proper to deny the effect of higher education just because of the era of the data. From the Medieval Age to the end of 19th century, the number of university was extremely rare. Thus few ordinary people could go to university during these ages. The young men from upper class could go to university, but they had few opportunity to experience life of common people, so that they could not create the greatest achievements. That is the reason of this research result. After 19th century, universities emerged quickly and lots of common have opportunity to go to university. Therefore, more and more outstanding academic writers have achieved great success in literature. This is worth of further research.

\section{References}

[1]G.C.Thornley and G. Roberts. An Outline of English Literature (Longman Group Ltd., England 1984).

[2]M. Drabble. The Concise Oxford Companion to English Literature (Oxford University Press, England 2007).

[3]C.S. Lewis. Studies in Medieval and Renaissance Literature (Oxford University Press, UK 1998).

[4]Information on https://en.wikipedia.org/wiki/William_Shakespeare.

[5]Information on https://en.wikipedia.org/wiki/Percy_Bysshe_Shelley.

[6]B. S.Liu. A Short History of English Literature (Henan People’s Publishing House, China 2007).

[7]S.R. Wang. Selected Readings in British Literature (Higher Education Press, China 2001).

[8]W.R. Wu. History and Anthology of English Literature (Foreign Language Teaching and Research Press, China 2013). 